\title{
Voltando aos registros paroquiais de Minas colonial: etnicidade em São José do Rio das Mortes, 1780-1810*
}

Returning to the Parish Registers of Colonial Minas Gerais: ethnicity in São José do Rio das Mortes, 1780-1810

Douglas Cole Libby **

Zephyr Frank ${ }^{* * *}$

\section{Resumo}

Este artigo trata dos complexos temas de etnicidade e classificação social no Brasil dos séculos XVIII e XIX. Bases de dados substanciais, de fontes primárias distintas, permitem vislumbrar um quadro integrado dessa complexidade, tal como evoluiu nas Minas Gerais. A lógica no uso das categorias étnicas/de cor e sociais emerge pelo cruzamento de nomes e características individuais nos registros de batismo e de casamento e em listas nominativas. O texto focaliza a paróquia de São José do Rio das Mortes e fornece respostas preliminares para questões relativas às práticas de maternidade e de casamento, sugerindo como designações étnicas e de cor se consolidaram ao longo de várias gerações. Os achados apontam para a pre-

\begin{abstract}
This article addresses the complex themes of ethnicity and social classification in eighteenth- and nineteenth-century Brazil. The use of large data bases, derived from independent primary sources, makes it possible to envision the outline of that complexity as it evolved in Minas Gerais. Ethnic/color and social categories are carefully examined and the logic of their use begins to emerge through the intersecting of names and individual attributes as they appear in baptismal and marriage registers, as well as in nominal lists. As a detailed case study of the parish of São José do Rio das Mortes, it furnishes preliminary answers to queries about maternity and marriage practices and sheds light on how ethnic and color designations were consolidated
\end{abstract}

\footnotetext{
* Este artigo é uma versão modificada e ampliada de "Exploring Parish Registers in Colonial Minas Gerais, Brazil”, publicado em Colonial Latin American Historical Review, v.14, n.3, p. 213-244, 2005.

** Professor Associado de História da UFMG, Centro de Estudos Mineiros, Fafich/UFMG. Av. Antônio Carlos, 6627, Campus Universitário. 31270-901 Belo Horizonte - MG - Brasil. dclibby@ fafich.ufmg.br

*** Professor Adjunto de História, Stanford University, Department of History, 450 Serra Mall, Building 200, Stanford - CA - 94305-2024 - USA.zfrank@stanford.edu
} 
valência de exogamia entre os escravos, enquanto a endogamia e, talvez, até mesmo um processo de racialização teriam predominado entre a população livre e liberta de todas as designações étnicas e de cor.

Palavras-chave: etnicidade; cor; classificação social; exogamia; endogamia; racialização. across several generations. Finally, the findings point to a prevalence of exogamic unions among slaves, while endogamy and perhaps even a process of racialization held sway among the free and freed populations of all color and ethnic designations.

Keywords: ethnicity; color; social classification; exogamy; endogamy; racialization.

A etnicidade e a classificação social sempre foram temas complexos para a historiografia brasileira. O uso de várias bases de dados extensas, derivadas de fontes independentes, possibilita a elaboração de um quadro integrado dessa complexidade, tal como evoluiu nas Minas Gerais. Dessa forma, categorias étnicas ${ }^{1}$ e sociais são colocadas em relevo, e a lógica do seu emprego começa a emergir pelo cruzamento de nomes e atributos individuais contidos nos registros de batismos e de casamentos e nas listas nominativas. Um estudo de caso pormenorizado da paróquia de Santo Antônio de São José do Rio das Mortes (hoje, Tiradentes) fornece respostas preliminares a questões acerca da maternidade e de práticas de matrimônio, além da maneira como a etnicidade se consolidava ao longo de algumas gerações.

$\mathrm{Na}$ América Portuguesa, a etnicidade se pautava em questões de naturalidade, entrelaçadas por posição social. A etnicidade poderia ser uma fonte de coesão e comunidade (por exemplo, padrões de casamentos endógenos), bem como de diferenciação social e mobilidade. As estruturas sociais também se fundamentavam em distinções de condição legal - livre, forra e escrava -, e essas distinções se entrecruzavam com a etnicidade por formas complexas que ainda não são inteiramente entendidas. Embora já exista uma extensa literatura historiográfica sobre etnicidade e condição legal, para avançar nossa compreensão sobre as muitas dúvidas que permanecem será preciso envidar esforços na correlação de registros paroquiais com outras fontes contemporâneas. ${ }^{2}$ Buscando preencher os espaços em branco desses registros, nossa pesquisa pode contribuir para jogar luz sobre o desenrolar da rotulação ao longo do tempo. Por exemplo, em vez de pressupor que aqueles espaços em branco dos registros paroquiais signifiquem 'brancura', os achados deste estudo demonstram que não poucos dos homens e mulheres arrolados sem qualquer designação racial eram, de fato, pessoas 'de cor'. ${ }^{3}$ Ademais, nossa abordagem reve- 
la em que medida o status de liberto às vezes se estendia além de uma geração ou desaparecia ao longo de uma única vida. Finalmente, o preenchimento das lacunas dos registros paroquiais faz que comecem a emergir certos padrões de casamento entre as categorias étnicas e sociais.

Para sanar os problemas inerentes à utilização de registros paroquiais como fontes únicas para a pesquisa, optou-se pela investigação de dados provenientes de uma lista nominativa eclesiástica contemporânea e referente à paróquia de São José do Rio das Mortes. O objetivo não é meramente confrontar as duas fontes, mas, na medida do possível, combinar informações relativas a indivíduos específicos e constantes nos registros e na lista nominativa. Esse processo cumpre a tarefa crítica de confirmar ou completar dados acerca da origem étnica e da condição legal de várias pessoas. Ao mesmo tempo, o cruzamento de dados coletados em múltiplas fontes constitui poderosa ferramenta na reconstrução de histórias de vida. O resultado é uma nova janela através da qual se pode vislumbrar a complexa história da etnicidade no Brasil colonial.

A Paróquia de Santo Antônio de São José do Rio das Mortes incluía o centro urbano da própria Vila de São José e nove capelas vinculadas à Matriz de Santo Antônio. ${ }^{4}$ Embora as descobertas do ouro tivessem desempenhado papel essencial no povoamento inicial da Vila e certo nível de atividade mineradora se mantivesse ainda nas primeiras décadas do século XIX, a maior parte da região composta pela freguesia foi ocupada originalmente com base na agropecuária. ${ }^{5}$ A paróquia se situa um pouco abaixo dos limites meridionais dos antigos distritos mineradores centrais da Capitania e, durante a primeira metade do século XVIII, os centros urbanos daqueles distritos eram mercados importantes para a diversificada produção da região de São José. Até meados dos Setecentos, gado bovino, queijos, toucinhos e grãos procedentes de São José haviam penetrado na praça mercantil do Rio de Janeiro e, de lá, eram redistribuídos para mercados menores, especialmente os litorâneos. ${ }^{6} \mathrm{O}$ comércio com o Rio e além aumentou enormemente no decorrer da segunda metade do século XVIII, diversificou-se ainda mais com a chegada da Corte em 1808, e permaneceu bem ativo ao longo de todo o século XIX. Com efeito, no longo prazo, esse abastecimento do mercado interno serviu como o principal esteio da economia regional. Mesmo que a Vila de São José tenha entrado em declínio, subretudo por causa da emergência da vizinha São João Del Rei como grande entreposto comercial, fica muito claro que a região como um todo foi marcada por uma prosperidade invejável. ${ }^{7}$

Nas Minas Gerais, a miscigenação constituiu, sem dúvida, um dos principais legados do chamado ciclo do ouro Setecentista. Durante a primeira metade do 
século, uma crônica escassez de mulheres brancas conduzia a inúmeros amasios entre homens brancos e mulheres escravas africanas ou de ascendência africana. Frequentemente, embora nem sempre, tais uniões resultavam na alforria de parceiras escravas e de seus filhos. Dessa forma, no decorrer do século, um segmento bastante substancial da população legalmente livre foi caracterizado por vários graus de ascendência africana, da mesma maneira que não poucos escravos foram rotulados como pardos e cabras (em princípio pessoas de 'três quartos' de ascendência africana), havendo também muitas variações de ascendência mista (inclusive a indígena). Quando da virada do século, o desequilíbrio entre os sexos havia desaparecido na população nascida livre e liberta. Inversamente, em função da preferência por peças masculinas que sempre caracterizou o tráfico negreiro internacional, os homens continuavam a superar as mulheres na população escrava ainda por boa parte do século XIX. ${ }^{8}$

Já que a etnicidade sozinha não basta como uma característica histórica diferenciadora, quando possível nossa análise leva em conta a condição legal - livre, liberta ou escrava - de indivíduos e de grupos. A principal fonte primária deste estudo consiste em 11.937 assentos de batismo, constantes dos registros de São José e datando de 1780 a $1810 .{ }^{9}$ Esse conjunto de dados se compõe por todos os assentos registrados no período dos trinta anos que cercam a elaboração de uma segunda fonte primária - o Rol dos Confessados desta Freguesia de S. Antonio da Villa de S. Joze $(1795)^{10}-$, a qual serve como pano de fundo para os assentos batismais e contém informações relativas a indivíduos específicos que não constam nestes. Embora o Rol dos Confessados não inclua crianças com menos de sete anos de idade, pois estas não se confessavam, informações acerca da etnia ou origem de quase todos os 10.929 indivíduos listados foram cuidadosamente anotadas pelos clérigos responsáveis por sua elaboração. Finalmente, no intuito de checar e/ou completar as informações relativas às designações étnicas, também se usaram 1.143 assentos de casamento datados de 1784 a $1810 .{ }^{11}$ Seja em termos quantitativos, seja no aspecto qualitativo, a interpretação de registros de batismos e de casamentos é dificultada por uma série de problemas. ${ }^{12}$

Os significados dos rótulos étnicos e de origem usados em Minas Gerais no final do século XVIII e na primeira metade do século seguinte são variados e complexos. A maioria dos estudiosos do Brasil colonial e das primeiras décadas dos Oitocentos aceita a noção de que a falta de informação relativa à cor de pele ou da condição de alguém pode ser interpretada como significando que ele/ela era branco e livre ou, mais precisamente, nascido livre. ${ }^{13}$ Tal pressuposto, no entanto, pode ser errôneo, pois os clérigos, escrivães de cartório e outras 
pessoas encarregadas de fazer registros nem sempre se preocupavam com a designação de etnia ou de condição legal, talvez porque tal informação não era considerada de importância em certas circunstâncias ou porque era dada como de conhecimento comum dentro da comunidade imediata. É preciso ter cuidado, portanto, para não superestimar o tamanho da população branca no Brasil, mesmo depois da Abolição da escravidão.

Não obstante as possíveis ambiguidades dos espaços vazios na documentação, em Minas a terminologia usada para designar os nativos de alguma ascendência africana decididamente se referia a tonalidades da pele. De modo geral, o termo pardo/parda correspondia a mulato(a), embora também pudesse ser usado para classificar pessoas de pele mais clara ou mais escura que o mulato 'clássico', e, ocasionalmente, pode ter sido usado para descrever indivíduos com graus variados de ascendência indígena. Embora o termo pudesse ter representado "um tipo de condição social", como querem alguns, ${ }^{14}$ nas Minas, a referência principal tratava da miscigenação de origens africanas e europeias.

Em algum momento antes de 1750, por exemplo, a ex-escrava Rosa, uma mina ${ }^{15}$ da África Ocidental, começou a dar à luz uma série de sete filhos, cujo pai era Antônio Moreira de Carvalho, homem branco de muitas posses provavelmente nascido em Portugal. Antônio nunca se casou com Rosa, mas reconheceu a paternidade de todos os filhos tidos com ela. Rosa assumiu os sobrenomes do parceiro (e quase certamente seu ex-proprietário) e, mais importante ainda para nossa discussão, todos os filhos do casal foram designados como pardos quando apareceram em circunstâncias variadas nos registros paroquiais, no Rol dos Confessados e em outros documentos, inclusive o testamento do único filho homem, Francisco Moreira de Carvalho, reconhecido em 1810 (Libby; Graça Filho, 2003, p.141). Uma das filhas, Theodora, casou-se com Antônio da Silva Abreu. Ambos foram arrolados no Rol dos Confessados como pardos, da mesma forma que os cinco filhos do casal.

Como já se sugeriu, 'pardo' também poderia se referir às pessoas de pele mais clara. A filha mais velha de Antônio e Rosa, Vitoriana Moreira Rosa, casou-se com um homem branco chamado Manoel Fernandes dos Santos. Os cinco filhos desse casal aparecem no Rol como pardos. Designações referentes à mistura racial, portanto, passavam de pais para filhos, e essa prática, repetida dezenas e dezenas de vezes no Rol, continuou na primeira metade do século XIX (Paiva, 1996, p.98-99).

Os especialistas concordam em que os filhos de escravas africanas eram designados como crioulos, mas não há consenso quanto à classificação daque- 
les de descendência além daquela segunda geração. Ao escrever sobre a cidade do Rio de Janeiro na primeira metade do século XVIII, Mariza Soares, por exemplo, observa:

O crioulo é o escravo filho de mãe gentia que nasce no âmbito da sociedade colonial. Corresponde, portanto, à primeira geração nascida na cidade e que supostamente, pelo menos nos primeiros anos de vida, mantém vínculos com a mãe e consequentemente com a cultura e a língua maternas. Talvez por isso o crioulo seja identificado ao mesmo tempo por seu nascimento no âmbito da sociedade colonial e por sua ascendência. Magdalena Costa, uma preta forra crioula, é filha natural de Josepha da Costa, uma preta-mina, e mãe do pequeno Custódio, escravo, batizado em 1746. Esta curta genealogia permite perceber que ser crioulo é uma condição provisória que afeta apenas uma geração de cada descendência, decorrendo daí, talvez, o fato de não constituir um grupo estável e com interesses comuns. ${ }^{16}$

Não há razão para questionar a interpretação da autora nesta instância particular, mas também é claro que o raciocínio não é inteiramente válido para Minas Gerais. Sem dúvida, urgem estudos comparativos acerca dos termos de designação étnica ou de origem usados nas várias regiões da América Portuguesa, especialmente Rio de Janeiro, Bahia, Pernambuco e Minas Gerais. De qualquer forma, mais uma vez, nas Minas a definição de 'crioulo' era bastante clara, pelo menos ao longo do período enfocado aqui: referia-se aos negros nascidos no Brasil, independente da origem dos pais - africana, nativa ou ambas - e sem implicações quanto à condição legal. O Rol dos Confessados nos fornece muitos exemplos disso. Entre os escravos pertencentes a José Gomes Pinheiro encontravam-se Sebastião, angola, ${ }^{17}$ e sua mulher, a benguela ${ }^{18}$ Rosa. O filho deles, Manoel, era arrolado como crioulo. ${ }^{19}$ Manoel Joaquim Martins e sua esposa Antônia Moreira da Silva aparecem como crioulos forros; os três filhos do casal eram considerados crioulos nascidos livres. Hilário Alvares Batista e Inácia de Oliveira eram crioulos nascidos livres, uma classificação que passaram para seus seis filhos. É óbvio, portanto, que, pelo menos em Minas, ‘crioulo' não era uma classificação aplicável apenas a uma única geração de indivíduos nascidos de pais africanos. De novo, o termo constituía essencialmente uma referência à ascendência africana e parece ter se mantido ao longo de várias gerações em torno da virada do século XVIII.

O termo 'cabra' constituía uma terceira designação de ascendência africana, usada com certa frequência nas Minas do século XVIII e nas décadas 
iniciais do XIX. Referia-se à prole de pais de origens mistas: um pardo (ou, talvez mais precisamente, um mulato) e o outro crioulo ou africano. Segundo o Rol dos Confessados, por exemplo, Antônio Ramassa do Sacramento era pardo, e sua esposa, Maria Antônia de Jesus, era crioula. O filho do casal, Manoel, foi arrolado como cabra. Ainda, a relativa flexibilidade do termo 'pardo' tornase patente ao observarmos que os três filhos do cabra Manoel Dias Cruz e de sua mulher parda, Francisca Maria de Jesus, figuravam como pardos. É curioso notar que, na documentação levantada até agora, nunca encontramos os termos 'quadrarão' ou 'oitavão', bastante comuns nas sociedades anglosaxônicas e francófonas. Com efeito, parece que esses termos teriam sido virtualmente desconhecidos no Brasil dos séculos XVIII e XIX. Isso sugere que os miscigenados de pele mais clara ou eram considerados pardos, ou simplesmente não eram sujeitos à descrição racial e, neste caso, poderiam ser considerados como brancos.

Ao refletir sobre essa flexibilidade da terminologia étnica/racial, um último e irresistível exemplo se impõe. Em 1795 a crioula forra Francisca Moreira era viúva, aos 55 anos de idade. Seus filhos, aparentemente nascidos livres, foram listados no Rol desta forma: Juliana, 32, parda; João, 26, e Roque, 24, cabras; José, 14, e Joaquina, 11, crioulos.

As designações usadas para identificar nativos de ascendência africana eram, portanto, caracterizadas por certa flexibilidade, mas, em Minas Gerais, seguiam padrões discerníveis. A rotulação de africanos era um empreendimento, ao mesmo tempo, mais complexo e menos preciso.

Por sua própria natureza, as designações atribuídas aos cativos africanos - muitas vezes chamadas de 'nações' - eram ambivalentes. ${ }^{20}$ Afinal, tais designações eram cunhadas nos dois lados do Atlântico e poderiam assumir significados distintos em determinadas regiões ou significados universais por todo o Atlântico Sul português envolvido, de uma forma ou outra, no tráfico negreiro internacional. Algumas designações se referiam a agrupamentos linguísticos, algumas a entidades políticas ou a localidades geográficas específicas, e outras, a grupos étnicos africanos específicos. Gwendolyn Midlo Hall adverte que:

Definidas e denominadas por traficantes do comércio atlântico, as etnias exportadas de vários pontos do litoral africano mudavam com frequência. As mesmas etnias eram exportadas, simultaneamente, de mais de um ponto do litoral. As origens litorâneas das viagens transatlânticas dos navios negreiros podem sugerir resultados que contrastam com as descrições étnicas constantes de documentação gerada nas Américas. 
A autora, no entanto, continua com esta observação:

a melhor evidência que temos acerca da distribuição dos africanos nos seus pontos de destino final se encontra na documentação que contém descrições das 'nações' dos escravos africanos, apesar do fato de que, às vezes, estas designações étnicas sejam pouco claras e equivocadas. ${ }^{21}$

Estudos recentes da História da África vêm contribuindo para um entendimento melhor de um bom número dos rótulos específicos e genéricos que fazem referência às origens. ${ }^{22}$ Por ora, porém, será necessário limitar a investigação aos termos encontrados nas nossas fontes mineiras. Quando, como frequentemente era o caso, os termos usados meramente indicavam o porto de embarque, podemos inferir muito pouco acerca da real origem dos escravos. Tal era o caso para a maior parte dos africanos que apareceram como pais ou padrinhos na amostra de assentos de batismo. Angola, por exemplo, foi o rótulo atribuído às peças partidas para as Américas através do porto de Luanda e cujas identidades étnicas se ligavam a numerosos grupos oriundos do vasto interior da África Central Ocidental. O mesmo pode ser dito com relação aos 'benguelas' e 'cabindas'; aqueles foram embarcados nos navios negreiros no porto de Benguela, no sul de Angola, onde traficantes baseados no Rio de Janeiro haviam se entrincheirado, pelo menos desde meados do século XVIII; ${ }^{23}$ já estes eram colocados nas embarcações no porto de Cabinda, ao norte de Luanda. Em princípio, o termo 'mina' se referia aos escravos transportados a partir do porto localizado junto à fortaleza de São Jorge da Mina, na África Ocidental, porém, como já se mencionou, ao adentrar a segunda metade do século XVIII, 'mina' havia se tornado um termo genérico para quase todos os indivíduos da África Ocidental. O termo 'congo' era igualmente impreciso, pois se referia às peças capturadas no imenso interior abraçado pelo rio Congo e seus muitos tributários.

Apenas quinze outras designações de africanos aparecem na nossa análise dos registros batismais, dez das quais se referem a grupos étnicos ou regionais da hinterland da África Central Ocidental: cabundás, cassanges, ganguelas, muhumbés, rebolas, loangos, quissamás, bambas, monjolos e songos. Mais três agrupamentos da África Ocidental foram representados: cabo verdes, couranos e saburus. Um único 'moçambique' da África Oriental aparece nos registros. Essa óbvia predominância de indivíduos da África Central Ocidental, nas Minas Gerais da virada do século XVIII, talvez seja indicativa da formação inicial ou precoce daquilo que Robert Slenes denomina de protonação banto no Su- 
deste do Brasil Oitocentista. ${ }^{24}$ Finalmente, há referências ocasionais aos 'pretos' ou às 'pretas', termos genéricos significando africanos(as) que parece ter sido empregado quando não se sabia nada sobre suas etnias ou origens. O único "gentio de Guiné" arrolado nos registros batismais pode ser considerado como um preto, já que, no final do século XVIII, o termo também havia se convertido em uma referência genérica para africano de origem desconhecida. ${ }^{25}$

Ao examinar a população feminina da Paróquia de São José, o que mais se destaca é a marcante predominância das nativas - brancas, pardas, crioulas e cabras - que, juntas, representavam nada menos que $87 \%$ das mulheres da freguesia (ver Tabela 1). Tal predominância nativa resultou de quase um século de tendências demográficas peculiares às sociedades dependentes do tráfico negreiro internacional. Sabe-se que o tráfico para a América Portuguesa e para as demais regiões escravistas do Novo Mundo favorecia muito o elemento masculino. O consenso é que, na média, a carga dos navios negreiros foi composta por dois ou três homens para cada mulher, ao passo que o número de crianças variava consideravelmente ao longo do tempo, sem, no entanto, modificar o desequilíbrio entre os sexos (Klein, 1999, p.166, 196).

Nas Minas, esse desequilíbrio parece ter sido maior ainda. As cifras para São José em 1795 resultam em razões de sexo (o número de homens para cada cem mulheres de uma dada população) que variaram entre 263 para os minas e 1.225 para o congos (entre os maiores grupos africanos, as razões de sexo correspondentes para os angolas, benguelas e rebolas eram, respectivamente 689, 427 e 417) (Libby; Paiva, 2000, p.104). A despeito do fato de que, entre os recém-chegados da África, as mulheres tenham sido amplamente superadas pelos homens, um fluxo constante de africanas chegava à Capitania. ${ }^{26}$ Quando essas minas, angolas, benguelas e outras geravam filhos, no entanto, elas não se reproduziam como africanas, pois sua prole era rotulada de acordo com as tonalidades de pele resultantes de combinações genéticas variadas e, portanto, levava rótulos de 'crioulos', 'pardos' ou 'cabras'. Nesse sentido, não surpreende que, no final do século XVIII, quando se elaborou o Rol dos Confessados, as mulheres africanas compunham menos de um terço da população escrava feminina e meros 13,2\% das forras de São José.

As práticas de alforria também influenciavam as configurações demográficas, pois a liberdade era concedida com maior frequência para escravos nascidos no Brasil, ao mesmo tempo que as mulheres, nativas e africanas, tendiam a ser agraciadas com a libertação em número maior (e, entre africanos, em proporções marcadamente maiores) que os homens. Ademais, como se vê na Tabela 1, ao longo do tempo, a miscigenação e a ascendência branca contribuíam 
decisivamente para a chance de se ganhar a liberdade, assim fazendo das pardas o maior grupo entre o contingente de mulheres libertas ou nascidas livres. Com efeito, as pardas constituíam o maior grupo de toda a população feminina. ${ }^{27}$ As crioulas nativas compunham o segundo maior segmento entre todas as mulheres, seguido de perto pelas mulheres brancas, que perfaziam um pouco mais de um quarto das mulheres da paróquia. Com base nessas cifras, derivadas do Rol dos Confessados, a expectativa seria de que a amostra de batismos de 1780 a 1810 resultaria em proporções mais ou menos iguais em termos da designação étnica/ de origem das mães.

Como se percebe na Tabela 2, se assumimos que a não declaração de cor refere-se a pessoas brancas, mulheres presumivelmente brancas parecem ter representado pouco mais da metade de todas as mães, achado que requer alguma reflexão quanto à natureza e à qualidade dos registros paroquiais como fontes primárias. ${ }^{28}$ Os vigários eram nominalmente responsáveis pela elaboração e manutenção dos registros de batismo, casamento e óbito, mas, dado que algumas sedes de paróquias possuíam populações relativamente grandes e que muitas freguesias eram muito extensas, esses clérigos frequentemente dependiam de seus vários assistentes para trabalhar com os registros. A cronologia (e 'geografia') errática dos assentos fortemente sugere que, não raras vezes, os eventos sacramentais eram efetivamente anotados até mesmo vários anos depois de realizados. É razoável supor que os clérigos e outros assistentes das capelas mais distantes tenham feito anotações que, mais tarde, serviriam para elaborar o registro do assento. Tais práticas teriam sido sujeitas à omissão involuntária, inconsciente ou deliberada - de certas informações. Podemos até especular que os cuidados extraordinários empregados na identificação da designação étnica/origem de cada indivíduo, quando da elaboração do Rol dos Confessados, resultassem de uma reação do então vigário de São José, Manoel Gomes de Souza, ao desleixo que caracterizara seus antecessores e assistentes. Mesmo tendo sido essa a intenção, nossa amostra dos registros paroquiais constitui uma indicação nítida de que a falta de cuidados iria perdurar por bom tempo.

Em potencial, os assentos de batismo poderiam ser bastante elaborados. Além das informações essenciais relativas ao sacramento e ao próprio batizando (data, nome, legitimidade ou não, enjeitamento), os assentos, às vezes, incluíam anotações acerca da condição legal e da designação étnica/origem de um extenso grupo de pessoas. ${ }^{29}$ A lista incluía a mãe e o pai e, quando escravos, seus respectivos proprietários, o chefe do domicílio no qual uma criança abandonada estava sendo abrigada, os padrinhos e seus respectivos 
proprietários quando apropriado, o marido ou pai da madrinha e os respectivos proprietários quando estes eram cativos, bem como as ocasionais testemunhas. Em alguns casos envolvendo pais ou padrinhos oriundos de Portugal, os assentos tomavam as feições de verdadeiras árvores genealógicas, pois incluíam nomes e lugar de batismo dos avós e até de bisavós.

Em se tratando das camadas inferiores da sociedade, no entanto, a ancestralidade não parece ter constituído uma grande preocupação. Afinal, se era de conhecimento comum na comunidade imediata que, por exemplo, uma tal Maria da Silva era parda forra, por que tais informações triviais teriam de ser anotadas? Parece que, pelo menos no que diz respeito ao período aqui enfocado, tais atitudes desleixadas teriam sido responsáveis pela omissão de informações nos registros paroquiais, e não um silenciamento deliberado acerca de identidades étnicas ou raciais. ${ }^{30}$

O problema que se apresenta é que, com muita frequência, a falta de informação relativa à cor da pele ou à condição de um indivíduo é interpretada, erroneamente, como indicando, de maneira definitiva, que ele(a) era branco(a) e nascido(a) livre. Dado o que já se sabe sobre a composição da população feminina arrolada no Rol dos Confessados, no entanto, as cifras que aparecem na Tabela 2, indicando que as mulheres brancas teriam sido responsáveis por pouco mais da metade dos nascimentos na paróquia de 1780 a 1810, não podem ser aceitas como representativas da realidade. Os hábitos desleixados dos clérigos responsáveis pelos registros paroquiais resultaram em uma subnumeração considerável de forros e pessoas afrodescendentes. Pensando nas proporcionalidades encontradas no Rol e demonstradas na Tabela 1, seria perfeitamente razoável supor que, pelo menos metade das 5.717 mulheres cuja designação étnica/origem não apareceu nos registros batismais, fossem pessoas nascidas livres ou forras e de ascendência africana ao menos parcial. ${ }^{31}$

Tal suposição reduziria a participação das brancas a aproximadamente um quarto das mães registradas - com certeza, uma cifra aceitável nessas circunstâncias. Especular quanto à distribuição das nascidas livres e forras por designação étnica/origem ou das mães escravas não identificadas, não seria nada prudente. Além disso, a Tabela 2 indica que cerca de $36 \%$ dos batizandos eram filhos de mães escravas, proporção que muito provavelmente reflete a realidade da época. As diversas imposições da escravidão no Brasil sistematicamente mantinham as taxas de natalidade dos cativos abaixo daquelas dos livres, o que explicaria por que a participação escrava nos batismos de São José ficou abaixo da proporção de escravos na população paroquial total.

A Tabela 2 demonstra que pouco menos de $95 \%$ das mães escravas eram 
identificadas de acordo com a designação étnica/origem. A distribuição por grupos étnicos e de origem parece corresponder de maneira bastante razoável às respectivas proporções da população escrava total, já que, por exemplo, as crioulas nativas e as benguelas formavam as duas maiores categorias de mães. ${ }^{32}$ Além do fato de que elas, de longe, compunham o maior segmento de escravas, a predominância das crioulas entre as mães certamente foi aumentada por sua capacidade de atrair tanto africanos quanto nativos como maridos ou parceiros. Pode-se afirmar o mesmo com relação às pardas e cabras. Para além disso, no entanto, a amostra é simplesmente limitada demais para permitir análises mais aprofundadas.

Deve-se lembrar que, em função dos já mencionados problemas encontrados nos registros paroquiais, alguns cruzamentos experimentais foram empreendidos no intuito de aumentar a identificação da designação étnica/origem entre mulheres escravas. Ao rearranjar a base de dados de batismos, usando a ordem alfabética dos proprietários de escravos, tornou-se possível localizar, no Rol dos Confessados, certo número de mães sem designação (e, quando casadas, os respectivos esposos escravos). No Rol, todos eram, invariavelmente, identificados pelo etnia/origem. O mesmo tipo de cruzamento foi empregado usando a base de dados dos casamentos, o que também permitiu a identificação dos rótulos raciais aplicados aos esposos escravos. ${ }^{33}$ Esses procedimentos exigem paciência e bastante tempo, mas, uma vez que melhoram sensivelmente a qualidade dos dados obtidos nos registros paroquiais, justifica-se a sua aplicação a conjuntos mais amplos de dados dos registros incluindo, no caso, os nascidos livres e os libertos - e a utilização, não apenas do Rol, mas, também, de material censitário datado da década de 1830, bem como dos conjuntos completos de registros de casamentos e de óbitos. Com efeito, em termos de pesquisas que miram questões relacionadas à etnicidade e à condição legal, os registros batismais mineiros não são fontes particularmente fecundas, e, portanto, é possível que o cruzamento com outros documentos seja a única maneira de garimpá-los da maneira mais proveitosa.

Não obstante os problemas apresentados pela subnumeração, os registros de batismo de São José nos rendem resultados importantes ao examinar as taxas de legitimidade de acordo com a condição legal das mães. ${ }^{34}$ Entre as mães nascidas livres (sem dúvida, incluindo libertas não identificadas e sem designação de cor e outras mães de ascendência africana), a taxa de legitimidade ficava no nível respeitável de $87,9 \%$, comparável às taxas ibéricas do início do século XIX. ${ }^{35}$ Não se pode perder de vista, porém, que praticamente todas as crianças abandonadas - os expostos - eram brancas ou de tonalidade de pele 
mais clara, pois, de modo geral, os proprietários vigiavam de perto suas escravas grávidas, justamente para evitar o abandono, uma condição que, teoricamente, libertava essas crianças. Ademais, as Câmaras locais, em princípio responsáveis pelos cuidados com os expostos, não hesitavam em devolver crianças escravas e, às vezes, rejeitavam crianças de pele escura, leiloando-as como escravos, assim evitando as despesas com amas de leite. ${ }^{36}$

Ao juntar os batismos de crianças abandonadas aos do segmento de ilegítimos gerados por mães nascidas livres, a taxa de legitimidade deste cai para cerca de 75\%, proporção provavelmente mais representativa da realidade dessa conjuntura de virada do século. ${ }^{37}$ Entre as mães listadas como forras, a taxa de legitimidade ficou em $1,8 \%$, resultado que corrobora estudos anteriores sugerindo um aumento constante da legitimidade entre as libertas no decorrer do século XVIII. Não é possível determinar quais teriam sido os efeitos da subnumeração de mães forras, mas a taxa de legitimidade para São José é muito semelhante à encontrada para a paróquia vizinha de São João Del Rei $(44,5 \%)$ ou para uma das paróquias que compunham a capital colonial de Minas, Vila Rica (45\%), durante o mesmo período aproximado. ${ }^{38}$ Vistos ao longo do tempo, os dados sugerem que, entre os nascidos livres, as taxas de legitimidade se encontravam em elevação após 1800.

Já para as taxas de legitimidade entre os escravos, os dados não indicam nenhuma tendência clara, seja para baixo, seja para cima. ${ }^{39}$ De qualquer forma, pouco menos de dois quintos dos rebentos de mães escravas eram registrados no assento de batismo como legítimos. Esses achados apoiam a noção de que a legitimidade escrava nas Minas aumentava lentamente ao longo do século XVIII. A taxa de 39\% para São José, de 1780 a 1810, era quase igual à de São João para $1808-1810-40,6 \% .{ }^{40} \mathrm{~A}$ taxa correspondente para Vila Rica, no entanto, ficava em menos de $20 \%$, o que quase certamente indica que as famílias escravas da região de São José/São João gozavam de maior estabilidade, graças, talvez, a uma economia que, na virada do século, já havia superado quaisquer efeitos negativos provocados pelo declínio na produção aurífera. O que é óbvio é que várias questões relacionadas à legitimidade e à família merecem mais estudos. ${ }^{41}$

Antes de examinar a etnicidade entre mães solteiras escravas e casais escravos, um pequeno detalhe sobre a condição dos filhos de escravas na hora do batismo mostra-se revelador e merecedor de alguma reflexão. No conjunto de 4.274 batismos de filhos de escravas, meros 56 receberam sua libertação como parte da cerimônia sacramental, ou seja, como se dizia na época, foram "alforriados na pia". Em cinco desses casos, os pais listados têm sobrenomes, 
quase que certamente indicando serem forros ou nascidos livres e muito provavelmente indicando que tivessem comprado a liberdade dos filhos. Surpreendentemente, apenas oito dos alforriados eram legítimos, e os pais de três deles eram nascidos livres ou libertos. A vasta maioria dessas crianças alforriadas foi registrada como natural - com efeito, a taxa de legitimidade de $15 \%$ era bem mais baixa que para o total dos batizandos escravos -, e os assentos não fornecem pistas sobre os motivos dessas libertações.

O que se destaca aqui é que, na São José da virada do século, a taxa de alforria infantil não passava de $1,3 \%$. Em contraste marcante, a taxa correspondente para Vila Rica do período 1712-1810 ficava em 5,6\%, embora pareça que, até o final do século XVIII, as alforrias de recém-nascidos tivessem passado por rápido declino, tanto em Vila Rica, quanto em São José (Libby; Botelho, 2004, p.78; Libby; Graça Filho, 2003, p.121). Tais achados apontam para uma conjuntura específica, da virada do século, no qual proprietários eram bem menos propícios a libertarem escravos valiosos, independente das idades destes. Ao examinar dois estudos recentes, ${ }^{42}$ torna-se tentador levantar a hipótese de que as importações de escravos para Minas tenham diminuído muito desde a segunda metade da década de 1780 até os anos 1812-1813, quando teria ocorrido uma retomada espetacular, porém efêmera, do tráfico negreiro para a Capitania. Parece lógico supor que proprietários de escravos que, por qualquer que fosse a razão, se encontrassem em dificuldades para repor seu estoque de peças, ficassem mais parcimoniosos na concessão de alforrias, não obstante as condições oferecidas.

Há boa dose de ironia nas estratégias que o pesquisador cuidadoso se vê forçado a adotar ao examinar a designação étnica/origem entre os casais de pessoas nascidas livres, de libertos ou de escravos e de mães solteiras escravas. Por um lado, o Rol dos Confessados fornece dados excelentes sobre os casais de nascidos livres e de forros, mas seu arrolamento sistemático dos escravos em ordem alfabética, típico dos Setecentos, faz que a identificação de casais ou famílias seja difícil, quando não impossível. ${ }^{43}$ Por outro lado, como já se discutiu, os registros batismais oferecem apenas informações esparsas referentes à etnia e à condição legal entre as pessoas livres e libertas. Graças ao cruzamento de informações sobre casais individuais encontrados nos registros do Rol dos Confessados e/ou nos registros de casamentos, foi possível determinar a designação étnica/origem de pelo menos um esposo entre um total de 776 casais escravos. Assim, a Tabela 3 mostra as designações étnicas/origem de esposos nascidos livres e libertos, tais como aparecem no Rol dos Confessados, ao passo que a Tabela 4 repete a mesma informação para casais escravos. ${ }^{44}$ 
A despeito da tendência geral em direção à endogamia racial ou étnica entre casais de livres e libertos, o que mais se destaca na Tabela 3 são as profundas marcas deixadas na sociedade de São José por um século de miscigenação. Os pardos e cabras perfaziam pouco mais de um terço de todos os indivíduos casados, apontando para uma notável propensão para a formação de famílias, uma vez que a proporção de miscigenados na população total paroquial ficava em menos de um quarto. Pelo menos em parte, tal propensão quase certamente refletia a importância do casamento e da formação de famílias nas estratégias empregadas por escravos na obtenção de suas alforrias. Com efeito, os alforriados representavam $39,6 \%$ de todas as pessoas casadas, enquanto os libertos e as libertas compunham apenas $12, \%$ da população total.

O que emerge desses achados é uma forte tendência ao cumprimento das normas da sociedade livre (e branca) por parte daqueles que compartilhavam algum grau de ascendência africana e, sobretudo, por aqueles que passaram pela experiência da escravidão. Os próprios impedimentos ao matrimônio e à formação familiar impostos pelo cativeiro provavelmente explicam, em boa medida, o apego de ex-escravos ao casamento.

Como a Tabela 3 demonstra, na São José de 1795 os casamentos racialmente mistos eram relativamente poucos. O matrimônio entre indivíduos de diferentes tonalidades de pele representavam meros $13,4 \%$ de todos os casamentos identificados no Rol dos Confessados. ${ }^{45}$ Emblematicamente, mais da metade desses casamentos mistos envolviam maridos brancos e mulheres pardas, e não apareceu um único caso de homem branco se casando com mulher de 'pura' ascendência africana. ${ }^{46}$ Por um lado, tem-se a impressão de que as uniões entre brancos e pardas ainda eram aceitáveis numa sociedade que, havia relativamente pouco tempo, emergira de uma situação de escassez crônica de mulheres. Por outro lado, fica bastante claro que uniões formais entre brancos e negros simplesmente não eram permitidas por uma hierarquia racial que ditava o comportamento aceitável para os brancos. Com efeito, as quatro mulheres brancas que se casaram com pardos deveriam ser bem corajosas, pois é certo que tais uniões não contavam com a aprovação da 'boa' sociedade. $\mathrm{O}$ corolário é que, pelo menos inicialmente, os pardos tinham de ser frutos de uniões ilícitas ou não reconhecidas, de modo geral, entre homens brancos e mulheres crioulas ou africanas.

Isso nos faz lembrar a história de Antônio Moreira de Carvalho, Rosa mina e seus sete filhos pardos. Mais comuns, no entanto, eram as uniões anônimas que apareciam implicitamente quando os clérigos insistiam em designar os batizandos como pardos. Pelo menos para nosso período, tais referências à 
designação étnica/origem dos batizandos praticamente se limitavam aos casos de pardos, cujas mães, normalmente, eram crioulas ou africanas e cujos pais eram desconhecidos. Essas anotações provavelmente representavam a condenação sutil, por parte do clero, de graus inaceitáveis de miscigenação.

Os achados apresentados na Tabela 3 sugerem que certo desgosto pela miscigenação estaria se tornando a norma em São José na virada do século. Mesmo que uniões racialmente mistas ainda estivessem bem visíveis no horizonte social, uma tendência para a endogamia já aparecia, não apenas entre os brancos, mas também entre os nascidos livres e libertos rotulados como pardos, crioulos e, até mesmo, africanos. O século XIX pode ter sido marcado pelas chamadas 'cores do silêncio', mas é preciso reconhecer que achados dessa natureza sugerem que os estudiosos devem prestar atenção aos padrões de normas sociais em que a endogamia tornava-se, cada vez mais, a regra para todos os agrupamentos de livres e libertos. ${ }^{47}$

Para os escravos, ou a endogamia era um luxo difícil de alcançar, ou era um objeto de pouca utilidade prática. De modo geral e como já se observou, para os escravos na América Portuguesa não era nada fácil contrair o matrimônio reconhecido pela Igreja. Em uma tentativa de proteger os casamentos entre escravos, a Igreja estabeleceu uma norma que, na realidade, teve o efeito oposto, na medida em que obstou incontáveis uniões formais entre cativos ao longo do tempo. As Constituições Primeiras do Arcebispado da Bahia, publicadas e distribuídas por toda a Colônia desde o início do século XVIII, pretendiam servir como adaptação da doutrina da Igreja para a realidade colonial. ${ }^{48}$

De acordo com as Constituições, os senhores eram responsáveis pela integridade do matrimônio sagrado de seus escravos. Em outras palavras, os proprietários de escravos casados estariam cometendo um pecado sério se permitissem a separação de casais escravos. ${ }^{49}$ A venda em separado de esposos escravos, é óbvio, tornou-se clara violação da doutrina da Igreja, doutrina essa que se colocou em oposição ao direito de se dispor livremente da propriedade privada - neste caso a mercadoria escrava. É muito provável que não poucos casamentos entre escravos de um mesmo proprietário tenham deixado de se realizar, por causa da influência da Igreja. $O$ certo é que os casamentos de escravos pertencentes a donos diferentes foram ficando cada vez mais raros ao longo do século XVIII e durante o século seguinte. Entre os 776 casais de escravos identificados nos registros batismais de São José, por exemplo, em apenas oito casos os esposos pertenciam a proprietários distintos. ${ }^{50}$

Diante de tais circunstâncias, é óbvio que o tamanho das posses de escravos desempenhou papel importante na possibilidade de casamento de casais 
de cativos: quanto menor a posse, mais difícil para os escravos encontrarem um parceiro compatível. Tal efeito teria ficado ainda mais poderoso se os escravos da América Portuguesa compartilhassem com seus companheiros do cativeiro na América do Norte o mesmo tabu contra a união entre primos. ${ }^{51}$ Embora ainda não estudado aqui, é difícil imaginar que um tabu de origem africana - e que foi respeitado entre os escravos norte-americanos até a emancipação - não fizesse parte da tradição dos mancípios no Brasil. E, neste caso, a formação de casais, especialmente entre escravos pertencentes a posses pequenas ou médias, teria se tornado ainda mais difícil.

Em Minas Gerais, as grandes posses de escravos eram muito raras. Ao longo do século XVIII, o tamanho médio das posses mineiras geralmente ficava em menos de dez, e os proprietários de um a dez escravos controlavam pouco mais de $40 \%$ do plantel da Capitania/Província, enquanto a proporção nas mãos de donos de 11 a 50 cativos chegava a quase $50 \% .{ }^{52}$ Em 1795, por exemplo, quase dois terços (65,7\%) dos escravos da Paróquia de São José residiam em plantéis de até vinte cativos. Somando-se as normas da Igreja, o apego aos direitos da propriedade privada, tabus africanos e o tamanho das posses, tudo parecia dificultar os casamentos de escravos. Tais limitações e obstáculos devem ter influenciado a composição dos casamentos efetivamente consumados e, sem dúvida, forçavam não poucos escravos a manterem uniões 'ilícitas' com parceiros de além dos muros da propriedade senhorial.

Embora a diferença não seja particularmente significativa, as crioulas nativas apareceram pouco mais frequentemente como mães solteiras (51\%) que como mães no geral $(47,4 \%)$. A participação das cabras nos dois grupos foi semelhante, mas as pardas parecem ter sido menos propícias a ter filhos fora do casamento que as demais escravas nativas. Entre as escravas africanas, havia uma tendência uniforme de as mães solteiras representarem proporcionalmente menos que sua respectiva participação entre todas as mães. Esse foi especialmente o caso entre as benguelas (mães solteiras - 10\%; todas as mães escravas - 13,8\%). Entre as crioulas e cabras, é muito provável que o tamanho relativamente modesto das posses mineiras representasse um obstáculo ao casamento formal. Neste caso, a grande proporção de mães solteiras e, consequentemente, as altas taxas de ilegitimidade quase certamente são mais indicativas da ampla existência de uniões entre escravos pertencentes a proprietários diferentes que de uma suposta promiscuidade inata nas senzalas. A identificação efetiva de tais uniões é quase impossível e representa um desafio difícil aos estudiosos que procuram entender melhor esse aspecto importante da vida escrava no Brasil. 
A Tabela 4 resume os dados retirados dos registros batismais relativos a quase trezentos casais de escravos (Libby; Botelho, 2004, p.78; Libby; Graça Filho, 2003, p.121). Como já explicado, para obter informações mais completas sobre cada esposo(a), foi necessário correlatar os registros de batismo e de casamento com o Rol dos Confessados. A despeito desses esforços, não foi possível determinar a designação étnica/origem de um dos esposos em $4,4 \%$ de todos os casos e, em outros $4,0 \%$ dos casos, nenhum dos esposos pôde ser identificado. Nos assentos de batismo propriamente ditos, a falta de informação foi bem maior do que a que aparece na Tabela 4, pois quase todas as informações 'adicionais' obtidas no Rol dos Confessados e nos assentos de casamentos se referiam às esposas e às mães solteiras. Uma possível explicação para esse fenômeno é que praticamente todas as mulheres escravas não identificadas quanto à etnia ou origem, de fato, teriam sido crioulas, cabras ou pardas e, portanto, tão conhecidas dentro das várias comunidades locais que compunham a paróquia (onde talvez tivessem nascido) que os clérigos não consideravam necessária uma identificação detalhada.

Entre os casais para os quais há informações acerca de ambos os esposos, duas características se destacam em especial. Primeiro, e em nítido contraste com a tendência entre os livres e libertos, as uniões endógenas entre escravos - entre pardos, crioulos, cabras e africanos - perfaziam $45,2 \%$ de todos os casamentos celebrados pela Igreja. Pouco mais de quatro quintos dessas uniões endógenas envolviam esposos africanos. Não obstante, no cômputo geral, os africanos eram igualmente propensos a escolher como parceiros escravos nativos. A exogamia, portanto, desempenhou papel importante entre os casais escravos de São José para os quais a designação étnica/origem foi indicada nas fontes.

Esses achados contrastam, de maneira bem distinta, com aqueles que se referem ao Recôncavo Baiano no final do século XVIII, pois lá, casais formados por africanos e nativos representavam pouco mais que $15 \%$ de todos os casamentos. Também contrastam com a situação no interior do Rio de Janeiro, onde a frequência dos casamentos 'mistos' decaiu de 23\% em 1790 para $11 \%$ em 1830, e com as práticas encontradas para o município cafeeiro paulista de Bananal na virada do século, quando as uniões formais entre africanos e nativos perfaziam meros $14,6 \%$ de todos os casamentos escravos. ${ }^{53} \mathrm{O}$ comportamento exógeno dos mancípios de São José, sem dúvida, coloca em xeque as interpretações historiográficas que insistem não apenas em que os africanos se dividiam, de maneira irreparável, entre seus agrupamentos 'tribais', mas também que não se davam bem com os escravos nativos do Brasil. 
Mesmo assim, os padrões desvelados aqui não podem simplesmente ser transpostos para todas as uniões entre escravos, até mesmo as uniões consensuais ou os relacionamentos 'escondidos' ${ }^{54}$ mantidos entre cativos pertencentes a donos diferentes. É plausível sugerir que a maioria dessas relações envolvesse uniões entre escravos pardos, crioulos e cabras que, desde a infância, faziam parte das mesmas comunidades e simplesmente não tinham opções viáveis de parceiros dentro das próprias posses. A segunda característica a salientar na Tabela 4 é a enorme preponderância de africanos entre os esposos homens na São José da virada de século.

Aqui, as marcas indeléveis do tráfico negreiro internacional são facilmente discerníveis. Numa população escrava na qual os homens superavam as mulheres por uma razão acima de 2,5 para 1, os africanos representavam pouco mais de $70 \%$ da população masculina, enquanto $67 \%$ das mulheres eram crioulas, pardas e cabras (Libby; Paiva, 2000, p.104). Nessas circunstâncias, a exogamia parece ter sido virtualmente inevitável. Ao mesmo tempo, não há como não concluir que, no mercado matrimonial, as mulheres escravas gozavam de boa vantagem sobre seus companheiros homens. De qualquer forma, e, mais uma vez, diante das restrições impostas sobre a escolha de parceiros pelo tamanho relativamente pequeno da maioria das posses e pela provável aderência às tradições africanas, as escravas nativas parecem ter preferido o sangue novo encorpado nos escravos africanos sobre o de seus irmãos nativos. As mulheres africanas, por sua vez, demonstravam preferência por parceiros do seu continente de origem, embora, na amostra, em torno de $12,3 \%$ delas tenham escolhido maridos nativos. Urgem, no caso, novas pesquisas, especialmente acerca das diferenças de idade entre os parceiros de casamentos escravos, diferenças que talvez venham a revelar padrões distintos por gênero e por etnia. ${ }^{55}$

Ao examinar os casais nos quais um ou ambos os esposos eram africanos, emerge um quadro mais detalhado, um quadro no qual prevalecia, de maneira bem clara, uma tendência à exogamia. A Tabela 5 inclui as designações étnicas / origens específicas de esposos africanos. Reconhecemos que nossa análise aqui baseia-se em números reduzidos, mas, a presença de homens benguelas era relmente notável, ainda mais quando se recorda que eles, ao menos no Rol dos Confessados, não constituíam o maior grupo de africanos masculinos. Com efeito, os benguelas compunham mais de dois quintos de todos os maridos constituintes desse subconjunto de casais escravos. Cerca de $45 \%$ desses benguelas haviam se casado com esposas nativas, pouco mais de um quarto se uniam a mulheres benguelas, e o resto se juntou com africanas de outros agrupamentos. Dois terços das mulheres benguelas se casaram com homens 
benguelas, mas algumas se uniam com nativos e outros africanos. Por uma margem pequena, os angolas preferiam as mulheres nativas às do seu próprio grupo e as demais escravas africanas, enquanto os homens congos se casavam com escravas nascidas no Brasil com frequência duas vezes maior que com suas companheiras africanas. Da mesma forma, as crioulas encontravam parceiros entre praticamente todos os agrupamentos africanos que aparecem nos registros batismais, enquanto os crioulos se uniam, predominantemente, com mulheres benguelas e angolas.

O que mais se salienta é que os casais endógamos compostos, de maneira 'pura', somente por africanos perfaziam apenas um quarto de todos os casamentos listados na Tabela 5 (a e b). A amostra é pequena, e é bem possível que seja representativa apenas do período relativamente curto aqui focalizado, mas, mesmo assim, fica a sugestão de que a exogamia era uma tendência entre os escravos das Minas. ${ }^{56}$

Importa reiterar aqui que, por si sós, os registros paroquiais de Minas Gerais não constituem fontes ideais para a análise de questões relacionadas à etnicidade dos vários segmentos da população dos séculos XVIII e XIX. Para produzir achados mais completos e consistentes, os dados provenientes de registros paroquiais precisam ser cruzados com dados de várias outras fontes. Quando se empregam esses cruzamentos referenciais, como nos esforços experimentais que informam o presente texto, é possível detectar tendências importantes. Durante o período enfocado, por exemplo, as taxas de legitimidade eram altas entre os nascidos livres de todas as cores, ao passo que os dados sugerem que a legitimidade estava em ascensão entre libertos e escravos. Embora os escravos continuassem a experimentar dificuldades para entrar em uniões matrimoniais, a incidência de casamento formal entre os alforriados de São José era surpreendentemente alta. As fontes também apontam para altos índices de miscigenação, legado do século XVIII para as Minas Oitocentistas. Fica claro que, até a virada do século, prevaleciam as uniões endógamas, tanto entre os nascidos livres, quanto entre os forros, muito embora as práticas da miscigenação nem de longe houvessem desaparecido nesses segmentos da população. Entre os escravos, e não obstante certas nuanças, a exogamia era muito mais comum nas uniões matrimoniais formais celebradas entre nativos e africanos. $\mathrm{O}$ que ainda não se sabe é se tais tendências se estendiam para trás, no século XVIII, e para frente, ao longo do século XIX. 
Tabela 1 - População feminina da Paróquia de São José, por designação étnica / origem e condição legal, 1795

\begin{tabular}{c|c|c|c|c|c|c|c|c}
\hline $\begin{array}{c}\text { Designação } \\
\text { étnica/origem }\end{array}$ & $\begin{array}{c}\text { Nascida } \\
\text { livre }\end{array}$ & $\%$ & Alforriada & $\%$ & Escrava & $\%$ & Totais & $\%$ \\
\hline Branca & 1.075 & 53,7 & - & - & - & - & 1.075 & 26,1 \\
Parda & 718 & 35,9 & 387 & 50,5 & 122 & 8,3 & 1.227 & 29,8 \\
Crioula & 120 & 6,0 & 230 & 30,0 & 794 & 54,1 & 1.144 & 27,8 \\
Cabra & 30 & 1,5 & 37 & 4,8 & 69 & 4,7 & z136 & 3,3 \\
Angola & - & - & 21 & 2,7 & 140 & 9,5 & 161 & 3,9 \\
Benguela & - & - & 9 & 1,2 & 199 & 13,6 & 208 & 5,0 \\
Mina & - & - & 57 & 7,8 & 60 & 4,1 & 117 & 2,8 \\
Congo & - & - & 2 & 0,3 & 20 & 1,4 & 22 & 0,5 \\
Rebola & - & - & 5 & 0,7 & 35 & 2,4 & 40 & 1,0 \\
Outras & $58^{*}$ & 2,9 & $19^{* *}$ & 1,5 & $28^{* * *}$ & 1,9 & 47 & 1,1 \\
\hline Totais & 2.001 & 100,0 & 767 & 100,0 & 1.467 & 100,0 & 4.117 & 100,0 \\
\hline
\end{tabular}

Fonte: Rol dos Confessados desta Freguezia de S. Antonio da Villa de S. Joze, Comarca do Rio das Mortes, deste prezente anno de 1795. Instituto Histórico e Geográfico de Tiradentes, Tiradentes (MG), Brasil, manuscrito.

* Inclui mestiça, bastarda e indivíduos cuja desginação étnica não pôde ser determinada.

${ }^{* *}$ Inclui preta, cabinda e ganguela.

*** Inclui ganguela, muhumbé, cassange, nagô e preta.

Tabela 2 - Mães dos batizandos, por designação étnica / origem e condição legal, paróquia de São José, 1780-1810

\begin{tabular}{c|c|c|c|c|c|c|c|c}
\hline $\begin{array}{c}\text { Designação étnica/ } \\
\text { origem }\end{array}$ & $\begin{array}{c}\text { Nascidas } \\
\text { livres }\end{array}$ & $\%$ & Libertas & $\%$ & Escravas & $\%$ & Totais & $\%$ \\
\hline $\begin{array}{c}\text { Sem designação } \\
\text { ("brancas por } \\
\text { inferência") }\end{array}$ & 5.717 & 95,7 & - & - & - & - & 5.717 & 51,3 \\
$\begin{array}{c}\text { Sem designação } \\
\text { (não-brancas) }\end{array}$ & - & - & 87 & 9,8 & 249 & 5,8 & 336 & 3,0 \\
Parda & 220 & 3,7 & 271 & 30,5 & 439 & 10,3 & 930 & 8,4 \\
Crioula & 25 & 0,4 & 445 & 50,1 & 2024 & 47,4 & 2.494 & 22,4 \\
Cabra & 13 & 0,2 & 33 & 3,7 & 207 & 4,8 & 253 & 2,3 \\
\hline
\end{tabular}




\begin{tabular}{|c|c|c|c|c|c|c|c|c|}
\hline Angola & - & - & 7 & 0,6 & 420 & 9,8 & 427 & 3,8 \\
\hline Benguela & - & - & 14 & 1,6 & 590 & 13,8 & 604 & 5,4 \\
\hline Mina & - & - & 9 & 1,0 & 107 & 2,5 & 116 & 1,0 \\
\hline Congo & - & - & 1 & 0,1 & 38 & 0,9 & 39 & 0,4 \\
\hline Rebola & - & - & 1 & 0,1 & 152 & 3,6 & 153 & 1,4 \\
\hline Cassange & - & - & - & - & 13 & 0,3 & 13 & 0,2 \\
\hline Muhumbé & - & - & - & - & 8 & 0,2 & 8 & 0,1 \\
\hline Outras ${ }^{* *}$ & - & - & 20 & 2,3 & 27 & 0,6 & 47 & 0,4 \\
\hline Totais*** & 5.975 & 100,0 & 888 & 100,0 & 4.274 & 100,0 & 11.137 & 100,0 \\
\hline
\end{tabular}

Fontes: Ver Libby; Paiva, 2000, p.104.

* Mulheres livres (ou libertas) sem designação étnica/origem ou de condição social nos registros que "por inferência" seriam consideradas brancas.

** Inclui 31 pretas ou africanas de origem desconhecida, 4 ganguelas, 2 cabundas, 2 cabinda, 1 cabo verde 1 saburu, 1 songo e 1 moçambique.

*** Exclui os batismos de 704 expostos e de 96 escravos adultos africanos.

\section{Tabela 3 - Designações étnicas / Origem entre esposos nascidos} livres e libertos na paróquia de São José, 1795

\begin{tabular}{|c|c|c|c|c|}
\hline Marido/Mulher & Nascido livre & Alforriado & Totais & $\%$ \\
\hline Branco/Branca & 293 & & 293 & 46,1 \\
\hline Branco/Parda & 45 & & 45 & 7,1 \\
\hline Pardo/Branca & 1 & 3 & 4 & 0,6 \\
\hline Pardo/Parda & 38 & 132 & 170 & 26,8 \\
\hline Pardo/Crioula & 1 & 9 & 10 & 1,6 \\
\hline Pardo/Cabra & & 6 & 6 & 0,9 \\
\hline Pardo/Africana & & 1 & 1 & 0,2 \\
\hline Crioulo/Parda & & 3 & 3 & 0,5 \\
\hline Crioulo/Crioula & 5 & 57 & 62 & 9,8 \\
\hline Crioulo/Cabra & & 2 & 2 & 0,3 \\
\hline Crioulo/Africana & & 1 & 1 & 0,2 \\
\hline Cabra/Parda & & 3 & 3 & 0,5 \\
\hline Cabra/Crioula & & 3 & 3 & 0,5 \\
\hline
\end{tabular}


Voltando aos registros paroquiais de Minas colonial...

\begin{tabular}{c|c|c|c|c}
\hline Africano/Crioula & & 7 & 7 & 1,1 \\
Africano/Africana & & 11 & 11 & 1,7 \\
Outros* $^{*}$ & & 14 & 14 & 2,2 \\
\hline Totais & 383 & 252 & 635 & 100,0 \\
\hline
\end{tabular}

Fonte: Ver Tabela 1.

Nota: Uma vez que o Rol mais ou menos sistematicamente omite informações acerca da condição legal das esposas (aparentemente porque tal condição seguiria a dos maridos), imputamos o status dos maridos às esposas.

*"Outros" se refere aos casais em que pelo menos um dos membros era listado como mestiço(a) ou bastardo(a). Não foi possível determinar exatamente qual o significado da designação mestiço, muito embora a referência obviamente fossa à mistura de raças ou etnias, talvez misturas tão complexas que não coubessem em quaisquer descrições conhecidas aos clérigos. Os bastardos nasceram de mães indígenas e pais brancos que se recusavam reconhecer sua paternidade. A escassez de referências às pessoas de origem indígena é, ao mesmo tempo, estranha e preocupante. Ao que tudo indica, o processo de embranquecimento dos afro-brasileiros foi antecedido por um simples apagar dos habitantes indígenas originais da América Portuguesa e de seus descendentes.

Tabela 4 - Designações étnicas / Origem entre esposos escravos na paróquia de São José, 1780-1810

\begin{tabular}{c|c|c}
\hline Marido/Mulher & Quantidade & $\%$ \\
\hline Pardo/Parda & 10 & 0,9 \\
Pardo/Cabra & 1 & 0,1 \\
Pardo/Crioula & 2 & 0,2 \\
Pardo/Africana & 15 & 1,3 \\
Cabra/Parda & 3 & 0,3 \\
Cabra/Cabra & 3 & 0,3 \\
Cabra/Crioula & 6 & 0,5 \\
Crioulo/Parda & 5 & 0,4 \\
Crioula/Cabra & 5 & 0,4 \\
Crioulo/Crioula & 78 & 7,0 \\
Crioulo/Africana & 45 & 4,0 \\
Africano/Parda & 6 & 0,5 \\
Africano/Cabra & 16 & 1,4 \\
Africano/Crioula & 423 & 37,5 \\
\hline Continua na página seguinte
\end{tabular}




\begin{tabular}{c|c|c}
\hline Africano/Africana & 429 & 38,0 \\
Crioulo/Sem ident. & 3 & 0,3 \\
Africano/Sem ident. & 20 & 1,8 \\
Sem ident./Parda & 1 & 0,1 \\
Sem ident./Cabra & 2 & 0,2 \\
Sem ident./Crioula & 8 & 0,7 \\
Sem ident./Africana & 9 & 0,8 \\
Sem ident./Sem ident. & 38 & 3,4 \\
\hline Total & 1.128 & 100,0 \\
\hline
\end{tabular}

Fonte: ver Tabela 2.

Tabela 5 - Designações étnicas / Origem entre casais compostos por 1 ou 2 esposos africanos, São José, 1780-1810

\begin{tabular}{|c|c|c|c|c|c|}
\hline \multicolumn{3}{|c|}{ Casais compostos de um esposo africano e um nativo } & \multicolumn{3}{|c|}{ Casais compostos por esposos africanos } \\
\hline Marido/Mulher & $\mathrm{N}$ & $\%$ & Marido/Mulher & $\mathrm{N}$ & $\%$ \\
\hline Angola/Crioula & 107 & 30,7 & Angola/Angola & 71 & 24,4 \\
\hline Angola/Cabra & 2 & 0,5 & Angola/Benguela & 14 & 4,8 \\
\hline Angola/Parda & 1 & 0,3 & Angola/Congo & 3 & 1,0 \\
\hline Benguela/Crioula & 112 & 32,1 & Angola/Mina & 10 & 3,4 \\
\hline Benguela/Cabra & 5 & 1,4 & Angola/Rebola & 3 & 1,0 \\
\hline Benguela/Parda & 3 & 0,9 & Benguela/Angola & 8 & 2,7 \\
\hline Cabinda/Crioula & 5 & 1,4 & $\begin{array}{l}\text { Benguela/ } \\
\text { Benguela }\end{array}$ & 93 & 32,0 \\
\hline Cabo Verde/Crioula & 1 & 0,3 & $\begin{array}{l}\text { Benguela/ } \\
\text { Cassange }\end{array}$ & 3 & 1,0 \\
\hline Cabundá/Crioula & 9 & 2,6 & Benguela/Congo & 5 & 1,7 \\
\hline Cassange/Crioula & 1 & 0,3 & $\begin{array}{l}\text { Benguela/ } \\
\text { Ganguela }\end{array}$ & 1 & 0,3 \\
\hline Conga/Crioula & 22 & 6,3 & Benguela/Mina & 14 & 4,8 \\
\hline Congo/Parda & 1 & 0,3 & Benguela/Rebola & 22 & 7,5 \\
\hline
\end{tabular}


Voltando aos registros paroquiais de Minas colonial...

\begin{tabular}{|c|c|c|c|c|c|}
\hline Ganguela/Crioula & 5 & 1,4 & Benguela/Saburu & 1 & 0,3 \\
\hline Mina/Crioula & 12 & 3,4 & $\begin{array}{l}\text { Cabinda/ } \\
\text { Cassange }\end{array}$ & 1 & 0,3 \\
\hline Monjolo/Crioula & 1 & 0,3 & Cabinda/Mina & 1 & 0,3 \\
\hline Muhumbé/Crioula & 1 & 0,3 & Cabinda/Rebola & 1 & 0,3 \\
\hline Preto/Crioula & 1 & 0,3 & Cabundá/Angola & 3 & 1,0 \\
\hline Preto/Parda & 1 & 0,3 & $\begin{array}{l}\text { Cabundá/ } \\
\text { Benguela }\end{array}$ & 3 & 1,0 \\
\hline Rebola/Crioula & 17 & 4,9 & $\begin{array}{l}\text { Cabundá/ } \\
\text { Cassange }\end{array}$ & 1 & 0,3 \\
\hline Rebola/Parda & 1 & 0,3 & Cassange/Angola & 1 & 0,3 \\
\hline Crioulo/Angola & 12 & 3,4 & Congo/Angola & 4 & 1,4 \\
\hline Crioulo/Benguela & 14 & 4,0 & Congo/Benguela & 6 & 2,0 \\
\hline Crioulo/Ganguela & 1 & 0,3 & $\begin{array}{l}\text { Congo/Cabo } \\
\text { Verde }\end{array}$ & 1 & 0,3 \\
\hline Crioulo/Mina & 3 & 0,9 & Congo/Mina & 1 & 0,3 \\
\hline Cabra/Angola & 1 & 0,3 & Congo/Rebola & 2 & 0,7 \\
\hline Cabra/Rebola & 1 & 0,3 & $\begin{array}{l}\text { Ganguela/ } \\
\text { Benguela }\end{array}$ & 2 & 0,7 \\
\hline Pardo/Angola & 4 & 1,1 & $\begin{array}{l}\text { Ganguela/ } \\
\text { Ganguela }\end{array}$ & 1 & 0,3 \\
\hline Pardo/Benguela & 4 & 1,1 & Mina/Angola & 1 & 0,3 \\
\hline \multirow[t]{8}{*}{ Pardo/Mina } & 1 & 0,3 & Mina/Mina & 1 & 0,3 \\
\hline & & & Monjolo/Rebola & 1 & 0,3 \\
\hline & & & Monjolo/Mina & 2 & 0,7 \\
\hline & & & Preto/Benguela & 1 & 0,3 \\
\hline & & & $\begin{array}{l}\text { Quissama/ } \\
\text { Benguela }\end{array}$ & 1 & 0,3 \\
\hline & & & Rebola/Angola & 5 & 1,7 \\
\hline & & & Rebola/Ganguela & 1 & 0,3 \\
\hline & & & Rebola/Rebola & 2 & 0,7 \\
\hline Total & 349 & 100,0 & Total & 291 & 100,0 \\
\hline
\end{tabular}

Fonte: ver Tabela 2. 


\section{NOTAS}

${ }^{1}$ Não é fortuita a escolha dos termos etnicidade, etnia e étnico(a). Consideramos que tais termos se referem, da maneira mais abrangente possível dentro das discussões do momento atual, à noção de uma grande diversidade de rótulos ou de representações identitárias utilizados no passado escravista para designar africanos e seus descendentes. Embora os termos empregados para rotular tais descendentes não constituam etnias propriamente ditas, não encontramos outro termo de abrangência satisfatória.

${ }^{2}$ Ver, entre muitos outros, BOXER, Charles. Race relations in the Portuguese Colonial Empire, 1415-1825. Oxford: Clarendon, 1963; REIS, João José. "Identidade e diversidade étnicas nas irmandades negras no tempo da escravidão”. Tempo, v.3, p.6-32, 1997; KARASH, Mary. Slave life in Rio de Janeiro. Princeton: Princeton University Press, 1987; KARASH, Mary. "Minha nação: identidades escravas no fim do Brasil Colonial". In: NIZZA DA SILVA, Maria Beatriz (Org.). Brasil: colonização e escravidão. Rio de Janeiro: Nova Fronteira, 1999. p.127-135; PRANDI, Reginaldo. "De africano a afro-brasileiro: etnia, identidade, religião". Revista USP, v.46, p.52-65, 2000; SLENES, Robert. “The great porpoise-skull strike: Central African water spirits and slave identity in early Nineteenth-Century Rio de Janeiro". In: HEYWOOD, Linda M. (Ed.). Central Africans and cultural transformations in the American Diaspora. Cambridge: Cambridge University Press, 2002. p.183-208; SILVA, Alberto da Costa e. Um rio chamado Atlântico: a África no Brasil e o Brasil na África. Rio de Janeiro: Nova Fronteira, 2003; FARIAS, Juliana B.; GOMES, Flávio S.; SOARES, Carlos E. Libano (Org.). No labirinto da nações: africanos e identidades no Rio de Janeiro, século XIX. Rio de Janeiro: Arquivo Nacional, 2005.

${ }^{3}$ Trabalhos mais recentes vêm enfatizando que, além de sinalizar para a brancura da pessoa arrolada, a ausência de qualificação teria sido indicadora, sobretudo, da liberdade do indivíduo (ou, muitas vezes, do fato de ele/ela ter nascido livre). Cf. CASTRO, Hebe Maria Mattos de. Das cores do silêncio: os significados da liberdade no Sudeste escravista - Brasil, século XIX. Rio de Janeiro: Arquivo Nacional, 1995. p.104; CASTRO FARIA, Sheila de. A colônia em movimento: fortuna e família no cotidiano colonial. Rio de Janeiro: Nova Fronteira, 1998. p.108-109, 159. (Na nota 12 dessa página lê-se: "Por 'branco' estou-me referindo aos que não traziam registro de cor/condição. Reafirmo que 'branco' ou a ausência de referência à cor/condição significava a liberdade incondicional").

${ }^{4}$ Embora alguns documentos do século XIX se refiram a São José Del Rey, a vasta maioria das fontes dos séculos XVIII e XIX usa o termo São José do Rio das Mortes, o qual será empregado ao longo do presente texto. Da mesma forma, a despeito de referências ocasionais que especificassem a Matriz - Santo Antônio -, a maioria falava simplesmente da Freguesia de São José.

${ }^{5}$ LIBBY, Douglas Cole; PAIVA, Clotilde Andrade. "Manumission practices in a lateEighteenth-Century Brazilian slave parish: São José d'El Rey in 1795". Slavery and abolition, v.21, n.1, p.96-127, 2000; e LIBBY, Douglas Cole; GRAÇA FILHO, Afonso de Alencastro. "Reconstruindo a liberdade: alforrias e forros na freguesia de São José do Rio das Mortes, 1750-1850”. Varia Historia, v.30, p.112-151, 2003; TEIXEIRA, Maria Lúcia Resende Cha- 
ves. Família escrava e riqueza na comarca do Rio das Mortes: o distrito da Lage e o quarteirão do Mosquito. São Paulo: Annablume, 2007; FRANK, Zephyr. "Wealtholding in Southeastern Brazil, 1815-1860". Hispanic American Historical Review, v.85, n.2, p.223-257, 2005.

${ }^{6}$ PRADO JÚNIOR, Caio. Formação do Brasil contemporâneo: colônia. São Paulo: Brasiliense, 1976. p.197-203; LENHARO, Alcir Lenharo. As tropas da moderação: o abastecimento da corte na formação política do Brasil, 1808-1842. São Paulo: Símbolo, 1979; e FRAGOSO, João Luis Ribeiro. Homens de grossa aventura: acumulação e hierarquia na praça mercantil do Rio de Janeiro, 1790-1830. Rio de Janeiro: Arquivo Nacional, 1992, especialmente o capítulo 3 .

${ }^{7}$ GRAÇA FILHO, Afonso de Alencastro. A princesa do oeste e o mito da decadência de Minas Gerais: São João del Rei 1831-1888. São Paulo: Annablume, 2002. Ver também CAMPOS, Maria Augusta do Amaral. A marcha da civilização: as vilas oitocentistas de São João del Rei e São José do Rio das Mortes. Dissertação (Mestrado) - PPGH, Universidade Federal de Minas Gerais. Belo Horizonte, 1999.

${ }^{8}$ PAIVA, Clotilde Andrade. População e economia nas Minas Gerais do século XIX. Tese (Doutorado) - PPGHE, Universidade de São Paulo. São Paulo, 1996. p.210. Ver também RODARTE, Mário Marcos Sampaio. O trabalho do fogo: perfis de domicílios enquanto unidades de produção e reprodução na Minas Gerais Oitocentista. Tese (Doutorado) PPGD, Universidade Federal de Minas Gerais. Belo Horizonte, 2008.

${ }^{9}$ Centro de Documentação, Diocese de São João del Rei, Arquivo Paroquial de Santo Antônio de São José do Rio das Mortes (doravante citado como as APSASJRM), Livros de Batismo 8, 9, 10, 11, Livro de Batismo, Óbito e Casamento 20, manuscrito.

${ }^{10}$ Rol dos Confessados desta Freguezia de S. Antonio da Villa de S. Joze, Comarca do Rio das Mortes, deste prezente anno de 1795, Instituto Histórico e Geográfico de Tiradentes, Tiradentes, Minas Gerais, manuscrito. Em princípio esses documentos eram elaborados anualmente durante a quaresma. Embora poucos róis sobrevivam, os investigados até agora variam consideravelmente quanto à sua forma. O Rol de São José é uma compilação, sem paginação, de listas nominativas arroladas para a Matriz (com sede na Vila) e cada uma das nove capelas. Os indivíduos são listados dentro dos respectivos fogos de residência, e os fogos são organizados de acordo com uma ordem alfabética bastante aproximada dos primeiros nomes dos chefes de domicílio. Já que as folhas não são numeradas e dada essa organização, é virtualmente impossível fazer referências específicas aos casos ou exemplos encontrados no Rol.

${ }^{11}$ APSASJRM, Livros de Casamentos 24, 25, e 26, manuscrito.

${ }^{12}$ As questões trazidas pelas fontes serão tratadas na medida em que se apresentaram na discussão que segue. As fontes eclesiásticas investigadas aqui fazem parte de um amplo projeto de pesquisa que visa ao levantamento de dados produzido por oficiais cartorários, os tribunais e vários níveis da administração estatal colonial e provincial. Em função de o projeto ainda estar em andamento, é possível que alguns dados novos relativos ao período 
sob exame sejam encontrados, muito embora todos os registros ora em fase de transcrição para as bases de dados aparentemente datem de 1820 em diante.

${ }^{13} \mathrm{O}$ Rol dos Confessados é realmente um documento notável, pois utiliza as designações branco/branca em vez de omitir a informação sobre a cor.

${ }^{14}$ CASTRO FARIA, 1998, p.307; e CASTRO FARIA, Sheila de. "Damas mercadoras: as pretas minas no Rio de Janeiro, século XVIII-1850". In: SOARES, Mariza de Carvalho (Org.). Rotas atlânticas da diáspora africana: da Baía do Benim ao Rio de Janeiro. Niterói: Ed. UFF, 2007. p.101-134. Ver também MATOS, Hebe Maria. “A escravidão moderna nos quadros do Império Português: o Antigo Regime em perspectiva atlântica”. In: FRAGOSO, João; BICALHO, Maria Fernanda; GOUVÊA, Maria de Fátima (Org.). O antigo regime nos trópicos: a dinâmica imperial portuguesa, séculos XVI-XVIII. Rio de Janeiro: Civilização Brasileira, 2001. p.141-162.

${ }^{15}$ Como se sabe, no período sob exame o termo mina havia se tornado uma designação genérica para quase todas as pessoas oriundas da África Ocidental.

${ }^{16}$ SOARES, Mariza de Carvalho. Devotos da cor: identidade étnica, religiosidade e escravidão no Rio de Janeiro, século XVII. Rio de Janeiro: Civilização Brasileira, 2000. p.100.

${ }^{17}$ De modo geral, angola se referia aos africanos embarcados no porto de Luanda e, portanto, era um termo muito genérico que certamente encobria uma infinidade de etnias ou grupos de procedência.

${ }^{18}$ Termo genérico para escravos exportados a partir do porto de Benguela, no sul da Angola. Novamente, deve ter englobado diversas etnias e grupos de procedência.

${ }^{19}$ Esse exemplo clássico de um casal de escravos africanos produzindo um filho crioulo é uma das poucas instâncias na qual o Rol dos Confessados não apenas identificou claramente esposos escravos, mas também indicou o filho deles. O status matrimonial dos escravos não interessava para a maioria dos clérigos incumbidos da elaboração do arrolamento.

${ }^{20}$ Como afirma Soares: "Mesmo tendo um componente étnico e também cultural, as nações - aqui entendidas como um sistema classificatório que emerge do universo do tráfico atlântico - redefinam as fronteiras entre os grupos étnicos através da formação de unidades mais inclusivas, por mim definidas 'grupos de procedência' ... Assim sendo, as ditas 'nações', inicialmente uma identidade atribuída, acabam sendo incorporadas e servindo como ponto de referência para o reforço de antigas fronteiras étnicas ou para o estabelecimento de novas configurações identitárias". SOARES, Mariza de Carvalho. "Histórias cruzadas: os mahi setecentistas no Brasil e no Daomé". in: FLORENTINO, Manolo (Org.). Tráfico, cativeiro e liberdade: Rio de Janeiro, séculos XVII-XIX. Rio de Janeiro: Civilização Brasileira, 2005. p.134. Para identidades africanas em Minas Gerais, ver REZENDE, Rodrigo Castro. As nossas Áfricas: população escrava e identidades africanas nas Minas Setecentistas. Dissertação (Mestrado) - PPGH, Universidade Federal de Minas Gerais. Belo Horizonte, 2006.

${ }^{21}$ HALL, Gwendolyn Midlo. Slavery and African ethnicities in the Americas: restoring the links. Chapel Hill: University of North Carolina Press, 2005. p.26. Herbert Klein concorda 
com Hall: "Se é difícil precisar a oferta de mercadorias estrangeiras importadas por este mercado [africano], igualmente complexo é estimar a oferta de escravos. A origem destes e a maneira pela qual eram obtidos constituem duas áreas cujo detalhamento é bem problemático". KLEIN, Herbert S. The Atlantic slave trade. Cambridge: Cambridge University Press, 1999. p.115.

${ }^{22}$ LOVEJOY, Paul E.; TROTMAN, David V. (Ed.). Trans-Atlantic dimensions of ethnicity in the African diaspora. London: Continuum, 2003; CURTO, Joseph C.; LOVEJOY, Paul E. (Ed.). Enslaving connections: changing cultures of Africa and Brazil during the era of slavery. Amherst (NY): Humanity Books, 2004; e VANSINA, Jan. "Ambaca Society and the slave trade c. 1760-1845”. Journal of African History, v.46, p.1-27, 2005.

${ }^{23}$ SILVA, Rosa da Cruz e. "Benguela e o Brasil no final do século XVIII: relações comerciais e políticas”. In: PANTOJA, Selma; SARAIVA, José Flávio Sombra (Org.). Angola e Brasil nas rotas do Atlântico Sul. Rio de Janeiro: Bertrand Brasil, 1999. p.127-142.

${ }^{24}$ SLENES, Robert W. “'Malungu, Ngoma Vem!': África encoberta e redescoberta no Brasil”. Cadernos do Museu da Escravatura, v.1, p.7-8, 1995.

${ }^{25} \mathrm{Na}$ documentação estudada aqui, o termo negro(a) não apareceu. Tratava-se de um termo polivalente, podendo se referir a africanos ou nativos de ascendência africana, se bem que, a partir de meados do século XIX, tendia a significar simplesmente escravo, independente da origem.

${ }^{26}$ Há um vago consenso de que, em razão do declínio na produção aurífera, o ritmo do tráfico negreiro para Minas teria diminuído consideravelmente no final do século XVIII. Ver, por exemplo, BERGAD, Laird W. Slavery and the demographic and economic history of Minas Gerais, Brazil, 1720-1888. Cambridge: Cambridge University Press, 1999; MARTINS, Roberto Borges. "Minas Gerais e o tráfico de escravos no século XIX, outra vez”. In: Tamás SZMRECSÁNYI, Tamás; LAPA, José Roberto do Amaral (Org.). História econômica da independência e do império: coletânea de textos apresentados no I Congresso Brasileiro de História Econômica, Campus da USP, set. 1993. São Paulo: Hucitec; Fapesp, 1996. p.99-130; e LIBBY, Douglas Cole. "O tráfico negreiro e a demografia escrava nas Minas Gerais: um século e meio de oscilações”. In: FURTADO, Junia Ferreira (Org.). Sons, formas, cores e movimentos na modernidade atlântica: Europa, Américas e África. São Paulo: Annablume, 2008. p.457-479.

${ }^{27}$ Sobre as práticas de alforria em Minas, ver PAIVA, Eduardo França. Escravos e libertos nas Minas Gerais do século XVIII: estratégias de resistência através dos testamentos. São Paulo: Annablume, 1995; LIBBY; PAIVA, 2000; e LIBBY; GRAÇA FILHO, 2003.

${ }^{28}$ As fontes para a Tabela 2 são: Centro de Documentação, Diocese de São João del Rei, APSASJRM , Livros de Batismo 8, 9, 10, 11, Livro de Batismo, Óbito e Casamento 20; Bispado de São João del Rei, APSASJRM, Livros de Casamentos 24, 25, e 26; e Rol dos Confessados desta Freguezia de S. Antonio da Villa de S. Joze, Comarca do Rio das Mortes, deste prezente anno de 1795, Instituto Histórico e Geográfico de Tiradentes, Tiradentes (MG), Brasil. 
${ }^{29}$ A data se referia ao dia da celebração do sacramento. Para o período em foco, apenas alguns poucos assentos incluíam a data de nascimento. Referências à designação étnica/ origem dos batizandos eram muito raras, e geralmente se restringiam aos filhos pardos (ou filhas pardas) de mães solteiras crioulas ou africanas.

${ }^{30}$ Silenciamento, aqui, refere-se à noção de que, particularmente a partir da segunda metade do século XIX, o discurso oficial no Brasil passou a omitir referências à cor da pele na medida em que se tornava cada vez mais claro que, num futuro pouco distante, escravos e afro-brasileiros teriam de ser aceitos como cidadãos. Cf. CASTRO, 1995.

${ }^{31}$ Deve-se lembrar aqui que a Tabela 2 não inclui, por razões óbvias, os batismos de crianças abandonadas.

${ }^{32}$ É interessante observar que, ao levar em conta ambos os sexos, os benguelas constituíam o segundo maior grupo de africanos em São José, atrás dos angolas. Entre estes últimos, no entanto, os homens superavam as mulheres por uma razão de sete a um, ao passo que a razão equivalente para os benguelas era ligeiramente acima de quatro a um.

${ }^{33}$ APSASJRM, Livros de Casamentos 24, 25, e 26, manuscrito.

${ }^{34}$ Os batizandos foram considerados legítimos toda vez que ambos os pais apareciam no assento, a não ser nos poucos casos nos quais as crianças eram explicitamente arroladas como naturais, significando que os pais não eram formalmente casados. $\mathrm{O}$ termo natural foi usado em virtualmente todos os casos de ilegitimidade na amostra. Ao empregar o termo, os clérigos estendiam aos pais a oportunidade de se casarem no futuro, assim legitimando seus filhos naturais. É possível que, em alguns casos, o registro da criança como natural pudesse ser usado para encobrir os frutos de relações adúlteras (adulterinos), a prole de clérigos (sacrílegos), ou crianças nascidas de relações incestuosas (espúrios ou incestuosos). Para uma excelente análise dessas questões, ver LEWIN, Linda. "Natural and spurious children in Brazilian inheritance law from Colony to Empire: a methodological essay. The Americas, v.48, n.3, p.351-396, Jan. 1992.

${ }^{35}$ SCOTT, Ana Sílvia Volpi. "O pecado na margem de lá: a fecundidade ilegítima na metrópole portuguesa, séculos XVIII-XIX”. População e família, v.3, p.41-70, p.2000.

${ }^{36}$ NIZZA DA SILVA, Maria Beatriz. História da família no Brasil colonial. Rio de Janeiro: Nova Fronteira, 1998. p.212-213; e FRANCO, Renato Júnio. Desassistidas Minas: a exposição de crianças em Vila Rica, século XVIII. Dissertação (Mestrado) - PPGH, Universidade Federal Fluminense. Niterói, 2006.

${ }^{37}$ Deve-se observar que mesmo essa proporção menor desmente a noção de que a ilegitimidade teria sido a norma para todos os segmentos da sociedade mineira do Setecentos. Ver: SOUZA, Laura de Mello e. Desclassificados do ouro: a pobreza mineira no século XVIII. Rio de Janeiro: Graal, 1982. p.143-144. Para uma excelente discussão das crianças abandonadas nas Minas coloniais ver FRANCO, 2006; VENÂNCIO, Renato Pinto. "Nos limites da sagrada família: ilegitimidade e casamento no Brasil colonial". In: VAINFAS, Ronaldo (Org.). História e sexualidade no Brasil. Rio de Janeiro: Graal, 1986; e VENÂNCIO, Renato Pinto. Famílias abandonadas: assistência à criança das camadas populares no Rio 
de Janeiro e em Salvador: séculos XVIII e XIX. Campinas (SP): Papirus, 1999. Para São Paulo, ver BACELLAR, Carlos de Almeida Prado. Viver e sobreviver em uma vila colonial: Sorocaba, séculos XVIII e XIX. São Paulo: Fapesp; Annablume, 2001, especialmente capítulos 7 e 8. Por razões que ainda não foram esclarecidas, em toda a América Portuguesa a incidência do abandono de crianças recém-nascidas aumentou sensivelmente no final do século XVIII e nas primeiras décadas do século XIX.

${ }^{38}$ BRÜGGER, Sílvia Jardim. "Legitimidade, casamento e relações ditas ilícitas em São João del Rei, 1730-1850". In: SEMINÁRIO SOBRE A ECONOMIA MINEIRA, 9. Anais... Diamantina: Cedeplar/Face/UFMG, 2000. p.37-64; e LIBBY, Douglas Cole; BOTELHO, Tarcísio Rodrigues. "Filhos de Deus: batismos de crianças legítimas e naturais na Paróquia de Nossa Senhora do Pilar de Ouro Preto". Varia Historia, v.31, p.69-96, 2004. Para estudos anteriores sobre a família em Minas colonial ver RAMOS, Donald. "Marriage and the family in Colonial Vila Rica”. Hispanic American Historical Review, v.55, n.2, p.200-225, 1975; e RAMOS, Donald. "Single and married women in Vila Rica, Brazil, 1754-1838". Journal of Family History, v.16, n.3, p.261-282, 1991. Em termos cronológicos, a comparação mais relevante com dados de fora de Minas seria com aqueles levantados por Sheila de Castro Faria para a paróquia de São Salvador dos Campos dos Goitacases de 1754 a 1798. Entre os nascidos livres, a autora encontrou uma taxa de legitimidade de mais de $92 \%$, ao passo que, entre os libertos, a legitimidade ficava em impressionantes dois terços de todos os nascimentos. CASTRO FARIA, 1998, p.337. Para Sorocaba e São Paulo entre 1791 e 1810, BARCELAR (2001, p.187) encontrou uma taxa de legitimidade entre os legalmente livres de $88,5 \%$ (os cálculos incluem expostos).

${ }^{39}$ Para calcular as taxas de legitimidade entre os escravos, foi necessário excluir os batismos de africanos recém-chegados. Esses casos, embora em números limitados, demonstram um declínio nos batismos de africanos adultos, indicando um provável hiato no tráfico negreiro para Minas no período em foco. Ver: LIBBY, 2008, p.457-479.

${ }^{40}$ Os dados do estudo de BRÜGGER (2000, p.48) revelam que a taxa de legitimidade entre os escravos de São João diminuiu de 1810 até meados do século.

${ }^{41}$ Outra vez, os achados de Castro Faria servem para comparação aqui. No período de 1748 a 1798, a legitimidade escrava em Campos dos Goitacases ficava em 21,5\%, ao passo que na paróquia urbana de Santa Rita (Rio de Janeiro) alcançava meros 6,8\% em 1817. No ano de 1814, na paróquia rural de Jacarepaguá (nas redondezas da cidade do Rio de Janeiro), 29,3\% dos batizandos escravos eram legítimos (CASTRO FARIA, 1998, p.337, 342). Em seu estudo sobre a população escrava de Franca, São Paulo, Maísa Faleiros da Cunha encontra uma taxa de legitimidade de cerca de $45 \%$ durante a primeira metade do século XIX. CUNHA, Maísa Faleiros da. "A legitimidade entre os cativos da Paróquia Nossa Senhora da Conceição de Franca, século XIX” (paper apresentado no ENCONTRO NACIONAL DE ESTUDOS POPULACIONAIS, 16, Caxambu, MG, 20-24 set. 2004. p.7).

${ }^{42}$ CARRARA, Angelo Alves. Minas e currais: produção rural e mercado interno em Minas Gerais, 1674-1807. Juiz de Fora (MG): Ed. UFJF, 2007. p.133-134, 141, 336-346; e LIBBY, Douglas Cole. "O tráfico negreiro internacional e a demografia escrava nas Minas Gerais: 
um balanço preliminar”. In: RESENDE, Maria Efigênia Lage de; VILLALTA, Luiz Carlos. História de Minas Gerais: as Minas setecentistas. Belo Horizonte: Companhia do Tempo; Autêntica, 2008. p.462-465. A análise de Carrara baseia-se em documentação fiscal relacionada à importação de escravos. A de Libby, nos batismos de escravos adultos africanos.

${ }^{43} \mathrm{O}$ uso de listagens alfabéticas era pouco comum, mas mostrou-se tão efetivo no encobrimento de casamentos e famílias de escravos quanto as listas mais típicas que, primeiro, arrolavam os homens, do mais velho ao mais novo, e, depois, repetia a operação para as mulheres.

${ }^{44}$ Os dados da Tabela 4 se referem a casais individuais de escravos (muitos dos quais batizaram mais de uma criança) e não aos batismos de todas as crianças escravas legítimas.

${ }^{45}$ Um estudo recente de Vila Rica (mais tarde denominada Ouro Preto) nas primeiras décadas do século XIX encontrou uma taxa minúscula de casamentos etnicamente mistos menos de 1\% - entre a população livre. LOTT, Mirian Moura. Na forma do ritual romano: casamento e família em Vila Rica (1804-1839). São Paulo: Annablume; Belo Horizonte: PPGH/UFMG, 2008. p.109-113.

${ }^{46} \mathrm{Um}$ exame rápido dessas uniões entre brancos e pardas revela que, na maioria dos casos, os maridos brancos eram consideravelmente mais velhos que suas mulheres pardas.

${ }^{47}$ De CASTRO, 1995, especialmente p.103-116.

${ }^{48}$ VIDE, D. Sebastião Monteiro da. Constituições primeiras do Arcebispado de Bahia. Brasília: Senado Federal, Conselho Editorial, 2007. p.125.

${ }^{49}$ Para mais detalhes sobre essa política da Igreja, ver NIZZA DA SILVA, 1998, p.188-193; e CASTRO FARIA, 1998, p.310.

${ }^{50}$ Em pelo menos três, e provavelmente quatro, desses casamentos 'interplantéis', os respectivos donos parecem ter sido parentes muito próximos - provavelmente irmãos ou viúvos e os seus filhos. A sugestão é que a 'separação' desses casais pudesse ter resultado da partilha de bens após a morte do proprietário original. Sendo este o caso, a separação física dos casais teria sido pouco provável. Para efeitos comparativos, Castro Faria encontrou que, em Campos dos Goitacases, os casamentos de escravos pertencendo a donos diferentes representavam 2,9\% de todos os casamentos escravos durante o século XVII e 1,7\% ao longo do XVIII. CASTRO FARIA, 1998, p.316-317.

${ }^{51}$ GUTMAN, Herbert George. The black family in slavery and freedom, 1750-1925. New York: Vintage, 1976, especialmente o capítulo 2.

${ }^{52}$ COSTA, Iraci del Nero da. Populações mineiras: sobre a estrutura populacional de alguns núcleos mineiros no alvorecer do século XIX. São Paulo: Instituto de Pesquisas Econômicas, 1981. p.332; LUNA, Francisco Vidal. Minas Gerais: escravos e senhores: análise da estrutura populacional e econômica de alguns centros mineratórios, 1718-1804. São Paulo: Instituto de Pesquisas Econômicas, 1981, p.64, 87, 93, 98; LUNA, Francisco Vidal. "Estrutura e posse de escravos". In: LUNA, Francisco Vidal; COSTA, Iraci del Nero da. Minas colonial: economia e sociedade. São Paulo: Fipe; Pioneira, 1982. p.38-39; BERGAD, 1999, p.206-207; BOTELHO, Tarcísio Rodrigues. "População e escravidão nas Minas Ge- 
rais, c. 1720". ," In: XII ENCONTRO DA ASSOCIAÇÃO BRASILEIRA DE ESTUDOS DE POPULAÇÃO, 12. Anais..., 2000. p.5-9. Disponível em: www.abep.org.br; Acesso em: 12 ago. 2006 (consultar "Anais"); LIBBY; PAIVA, 2000, p.110; FRANK, 2005, p.228-229; e DANTAS, Mariana Libânio Resende. Black townsmen: urban slavery and freedom in the Eighteenth-Century Americas. New York: Palgrave Macmillan, 2008. p.60-64; LIBBY, 2008, p.457-479.

${ }^{53}$ SCHWARTZ, Stuart B. Sugar plantations in the formation of Brazilian society: Bahia, 1550-1835. Cambridge: Cambridge University Press, 1985. p.391-392; FLORENTINO, Manolo; GÓES, José Roberto. A paz das senzalas: famílias escravas e tráfico atlântico, Rio de Janeiro, c.1790-c.1850. Rio de Janeiro: Civilização Brasileira, 1997. p.147-152; e MOTTA, José Flávio. Corpos escravos, vontades livres: posse de cativos e família escrava em Bananal, 1801-1829. São Paulo: Annablume, Fapesp, 1999. p.261-265.

${ }^{54}$ Escondidos no sentido de que esses relacionamentos quase nunca aparecem nas fontes relevantes.

${ }^{55}$ Uma hipótese plausível, por exemplo, é que as mulheres escravas teriam preferido como maridos homens mais velhos, porque estes poderiam ter juntado algumas economias, as quais serviriam para a compra da alforria de esposas ou, postumamente, de viúvas. Professor Robert W. Slenes, da Universidade Estadual de Campinas (Unicamp), em conversa com os autores.

${ }^{56} \mathrm{Um}$ estudo recente, baseado em casais identificados em inventários post mortem e nos registros de casamento, aponta para a mesma tendência exógena. GRAÇA FILHO, Afonso de Alencastro; PINTO, Fábio Carlos Vieira; MALAQUIAS, Carlos de Oliveira. "Famílias escravas em Minas Gerais nos inventários e registros de casamento - o caso de São José do Rio das Mortes, 1743-1850". Varia Historia, v.23, n.37, p.184-207, 2007.

Artigo recebido em fevereiro de 2009. Aprovado em outubro de 2009. 